\title{
Optimizing Textile Dyeing Wastewater Irrigation through Physiochemical Attributes of Tomato, Plant Nutrient Use Efficiency and Pollution Load Index of Irrigated Soil
}

Jahidul Hassan ( $\sim$ jhassan@bsmrau.edu.bd)

Bangabandhu Sheikh Mujibur Rahman Agricultural University

Md. Mijanur Rahman Rajib

Bangabandhu Sheikh Mujibur Rahman Agricultural University

Masuma Akter

Bangabandhu Sheikh Mujibur Rahman Agricultural University

Md.Noor E Azam Khan

Bangabandhu Sheikh Mujibur Rahman Agricultural University

Shahjalal Khandakar

Dhaka University of Engineering and Technology

Farhan Khalid

The Islamia University of Bahawalpur

G. K. M. Mustafizur Rahman

Bangabandhu Sheikh Mujibur Rahman Agricultural University

\section{Research Article}

Keywords: wastewater, physiochemical, heavy metals, soil environment, tomato

Posted Date: January 7th, 2022

DOI: https://doi.org/10.21203/rs.3.rs-1156702/v1

License: (c) (i) This work is licensed under a Creative Commons Attribution 4.0 International License.

Read Full License 


\section{Optimizing Textile Dyeing Wastewater Irrigation through Physiochemical Attributes of Tomato, Plant Nutrient Use Efficiency and Pollution Load Index of Irrigated Soil}

Jahidul Hassan ${ }^{1 *}$, Md. Mijanur Rahman Rajib ${ }^{1 *+}$, Masuma Akter ${ }^{1+}$, Md. Noor-E-Azam Khan ${ }^{1}$, Shahjalal Khandakar', Farhan Khalid ${ }^{3}$, G. K. M. Mustafizur Rahman ${ }^{4}$

${ }^{1}$ Department of Horticulture, Bangabandhu Sheikh Mujibur Rahman Agricultural University, Gazipur1706, Bangladesh.

${ }^{2}$ Department of Textile Engineering, Dhaka University of Engineering and Technology, Gazipur-1701, Bangladesh.

${ }^{3}$ Faculty of Agriculture and Environment, The Islamia University of Bahawalpur, Pakistan.

${ }^{4}$ Department of Soil Science, Bangabandhu Sheikh Mujibur Rahman Agricultural University, Gazipur1706, Bangladesh.

*Corresponding Author's:

jhassan@bsmrau.edu.bd

mmrrajib@bsmrau.edu.bd

+ These authors contributed equally to this work 


\section{ABSTRACT}

This experiment considers the seven different stages of textile dyeing effluents on tomato crop production in order to diminish the excess effluent treatment plant (ETP) cost and farmers net input cost. Seven different stages waste water (WW) with ground water (control) were collected and analyzed for physiochemical as well as heavy metals properties. T8 (mixed effluent) crossed the limit of agricultural standard for almost all physiological parameters such as TDS, TSS, EC, BOD, COD affording the highest value. T8 also delivered the highest $\mathrm{Cl}^{-}$and heavy metals like $\mathrm{Cd}, \mathrm{Ni}, \mathrm{Cr}$ followed by $\mathrm{T4}\left(2^{\text {nd }}\right.$ wash after bath drain) < T7 (Fixing treatment water). As a consequence, these provided comparatively higher enrichment factor (EF), pollution load index (PLI) and sodium absorption ratio (SAR) to transform fresh soil into "severe" and "slightly to moderate" saline. Correlation matrix demonstrated that EF and PLI of heavy metals (except $\mathrm{Cd}, \mathrm{Ni}$ ) were negatively related to yield, while positively related to SAR and fruit abortion. Although T6 ( $2^{\text {nd }}$ wash after soaping) performed better in respect to growth, yield, yield attributes and nutrient use efficiency, principal component analysis (PCA) expressed that $T 2\left(2^{\text {nd }}\right.$ wash after scouring and bleaching) and T3 (enzyme treated water) also belong to T6 and T1 group (ground water). Therefore, T2, T3 and T6 could be used to vegetable crop production up to some extent and to reduce ETP and agricultural input cost.

Kew words: wastewater, physiochemical, heavy metals, soil environment, tomato

\section{Introduction}

Water being natural resource, is vital and crucial for the survival of all living organisms. About 44,538 cubic kilometers of water only 1 percent is fresh water where half of it in rivers, lakes and swamps. Readily accessible water for human use is about 0.007 percent of all sources on the planet and consumption rate increasing twice per year [1]. Due to uneven distribution Asia has far less comparison to Europe and America. Agriculture uses about $70 \%$ of freshwater resources which have accelerated due to population growth and rapid economic developments [2]. Likewise, urbanization as well as industrialization is rushing to consume a huge quantity of water. Most researchers have shown great interest in treatment, recycling and reuse of these industrial wastewater (WW). Among the different industries, textile industries are rapidly growing in Bangladesh and there were 1821 small and large knit dyeing industries in Bangladesh [3]. To dye $1 \mathrm{~kg}$ of cotton goods with reactive dyes requires an average of 70-150 L of fresh water, $0.6 \mathrm{~kg} \mathrm{NaCl}$ and 40 gms reactive dyes, alkalis and others pretreatment and dyeing auxiliaries [4]. WW from textile processing contains huge residue of dyestuff, which are major source of heavy metal, salt, organic halogens (AOX), acid, alkalis, carcinogenic aromatic amines and color [5,6].

Treated WW use for crop irrigation can improve growth and yield of herbaceous species [7] and can also enhance the economic benefits for farmers by reducing fertilizer application [8]. Previously, numerous researchers revealed that WW rich with valuable sources such as organic matter, macronutrient and micronutrient that is required by the plant for fertility and productivity of soil [9]. Other researchers found wastewater used for irrigation supply nitrogen $(\mathrm{N})$, phosphorus $(\mathrm{P})$ and potassium $(\mathrm{K})$ with heavy metal to plants and soil, thus increasing yields and quality [10-12]. Soils act as toxic chemical filters may absorb and retain heavy metals from WW. Due to continuous loading of pollutants and changes in $\mathrm{pH}$, the 
capacity of soils to retain toxic metals being reduced and thus soil may release heavy metals into groundwater or bioavailable for plant uptake [13].

WW should be applied under controlled conditions as to minimize hazards of agricultural products [14], soil and groundwater from toxic, pathogenic [15, 16], bacteria and virus contaminants [17]. It may accumulate toxic heavy metals such as cadmium ( $\mathrm{Cd})$, lead $(\mathrm{Pb})$, chromium ( $\mathrm{Cr}$ ) and Nickel (Ni) to the soil [18] and negative potential impacts on crop production, public health, soil resources and ecosystems $[19,20]$. Besides, human is subjected to a direct impact on health by contamination of soils due to the facts that soils are easily contacted and transferred to them [12, 21-23]. Reuse of WW not only provides significant amount of irrigation water, but also contributes to conserve potable resources and reduces the environmental impact related to the effluents discharge into water bodies $[15,17,24]$. Effluent treatment plant (ETP) can solve the negative issues, but due to expensive establishment and operating cost many industrialists have reluctance and dispose WW directly that bit by bit destroy fresh water sources as well. Seven different stages of textile dyeing water during manufacturing may examine and analyze separately in order to apply in long time vegetable crop cultivation. Positive upshot on agricultural crop production of one or more stages WW may reduce ETP cost for industrialist and net input cost for the farmers as well.

Several researchers worldwide have done research work related to WW impact on various vegetable and fruit crops and their consequences to soil, health and environment. None of them have done research regarding different stages of textile dyeing WW and consequence distress in crop, soil, health and environment. Therefore, seven different stages of textile dyeing WW along with ground water (control) were irrigated to tomato (Solanum Lycopersicon) to achieve the objectives: 1) to characterize the physiological, plant nutrient and heavy metals properties of different stages textile dyeing $W W, 2$ ) to evaluate the growth, yield and physiochemical quality of tomato under WW irrigated conditions, 3 ) to assess the suitable stages of textile dyeing WW for healthy plant and soil.

\section{Methods}

\section{Experiment design}

The study was conducted with tomato (Solanum lycopersicum) as the test plant at the Horticultural Research Farm and the Soil Science Laboratory of the Bangabandhu Sheikh Mujibur Rahman Agricultural University, Salna, Gazipur, Bangladesh. The sources of irrigation water for tomato cultivation were the different stages of textile dyeing wastewater (Table 1) and ground water was used as control. Before irrigation the water samples and soil used for tomato cultivation were analyzed to sort out the physiochemical characteristics. No pesticides and fertilizers were applied during the crop production to avoid the inclusion of foreign nutrients or chemicals to the existing study samples. The plant was grown in the earthen pots and subsequently, growth, yield and biochemical parameters were analyzed at different days after planting till harvest. After harvest, the irrigated soils were further analyzed to figure out the plant nutrient use efficiency by the cultivated plant (tomato); total residue in the soil after harvest; heavy metal enrichment factor and pollution load index of the wastewater irrigated soils. 


\section{Characterization of wastewater and groundwater}

\section{Selection of Textile dyeing factory}

Wastewater samples were collected from the Tex Euro BD Ltd, 20 tons dyeing capacity knit composite factory which is situated $10 \mathrm{~km}$ away from the study area. Due to the closer distance, it took very short time to collect the wastewater samples and analysis before changing physicochemical properties of wastewater.

\section{Selection of different stages textile dyeing wastewater}

There are several steps in knit dyeing process. Scouring and bleaching, dyeing, soaping, fixing and softening are very common steps in cotton (yarn and knit) fabric dyeing process. In some processes only less, harmful organic chemical is used. In enzyme treatment process, bio-polish enzyme is used. Enzyme is actually protein-based microorganism. Therefore, it has been assumed that the wastewater coming from this processing step would have no significant harmful impact on environment. On the other hand, in soaping, fixing and softening treatment process, organic based eco-friendly chemicals are used in most of the cases. In some process, only fresh hot or cold water is used to wash the fabric for cleaning. Therefore, effluents after different processing steps were selected for irrigation with the diversified features as treatment variables to cultivate tomato.

\begin{tabular}{clcl} 
Sample ID & \multicolumn{1}{c}{ Sample collection step } & Sample ID & \multicolumn{1}{c}{ Sample collection step } \\
\hline $\mathrm{T}_{1}$ & Groundwater (Control) & $\mathrm{T}_{5}$ & Neutralization treatment \\
$\mathrm{T}_{2}$ & $\begin{array}{l}\text { Second wash after scouring } \\
\text { and bleaching }\end{array}$ & $\mathrm{T}_{6}$ & 2nd wash after Soaping \\
$\mathrm{T}_{3}$ & Enzyme treated water & $\mathrm{T}_{7}$ & Fixing treatment water \\
$\mathrm{T}_{4}$ & 2nd wash after bath drain & $\mathrm{T}_{8}$ & $\begin{array}{l}\text { Mixed effluent from equalization } \\
\text { tank before ETP }\end{array}$
\end{tabular}

\section{Sample collection and preservation for analyses}

The effluents samples were carried out in 120 liters plastic container for using as irrigation purpose of tomato cultivation and labeled as T2-T8 and ground water was also preserved with the marking of T1 (control). Samples for effluents characterization were taken in two liters plastic bottles with good stoppers from the plastic container. Two drops of concentrated $\mathrm{HNO}_{3}$ were added to $1 \mathrm{~L}$ of sample of each treatment for heavy metal analysis while the rest $1 \mathrm{~L}$ sample was kept without adding any acid for the analysis of major ions. Bottles were thoroughly washed with $1 \mathrm{M} \mathrm{HCl}$ and rinsed several times with de-ionized water before sample collection. Sampling was carried out using the grab method except mixed effluent [25]. Among the seven studied TDW, six different stages of effluents were collected from the processing steps of dyeing whereas mixed effluent sample was taken from equalization tank those were discharged before purifying at ETP. Groundwater (GW) sample was collected as control treatment from supplied deep tube well water near the experimental site that is commonly used for irrigation purpose in the research field. The samples were brought to the Environmental laboratory, Dhaka University of Engineering 
and Technology (DUET), Gazipur and preserved at 40 $\mathrm{C}$ in a refrigerator to analysis the various physio-chemical characteristics adopting the procedures outlined in the standard procedures [26].

\section{Laboratory analysis of textile dyeing wastewater}

The physicochemical parameters such as $\mathrm{pH}$, temperature, color, electrical conductivity, dissolved oxygen (DO), chemical oxygen demand (COD), biochemical oxygen demand (BOD), total suspended solids (TSS), total dissolved solids (TDS) and nitrate $\left(\mathrm{NO}_{3}{ }^{-}\right)$, phosphate $\left(\mathrm{PO}_{4}^{-}\right.$ $\left.{ }^{3}\right)$, sulphate $\left(\mathrm{SO}_{4}{ }^{-2}\right)$, chloride $\left(\mathrm{Cl}^{-}\right)$and seven heavy metals were selected for their estimation in the selected TDW, GW and soil based on the earlier reports and the chemicals used for dyeing process. The $\mathrm{pH}$ and temperature of wastewater was determined using portable $\mathrm{HACH}$ pH meter. The primary buffers of $\mathrm{pH} 4.0$ (Phthalate), $\mathrm{pH} 7.0$ (phosphate) and pH 10.0 (borax) were used as references to calibrate the $\mathrm{pH}$ meter. Determination of other parameters such as colour, nitrate $\left(\mathrm{NO}_{3}{ }^{-}\right)$, sulphate $\left(\mathrm{SO}_{4}{ }^{-2}\right)$, phosphate $\left(\mathrm{PO}_{4}^{-3}\right)$ were carried out in the laboratory using DR-2800 ${ }^{\mathrm{TM}}$ portable spectrophotometer. Electrical conductivity was determined by conductivity meter (EC150, $\mathrm{HACH}$ ). Biochemical oxygen demand (BOD) was measured by dilution method [26]. Keeping samples for 5 days in an incubator at $20^{\circ} \mathrm{C}$ after measuring initial DO of samples, dissolve oxygen (DO) was measured by chemical method. Chemical oxygen demand (COD) was determined by dichromate digestion method. Chloride was determined by Mohr's silver-nitrate method. Suspended solids (SS) were measured gravimetrically while total solid was obtained by the sum of SS and TDS. Heavy metals (iron, copper, zinc, lead, cadmium, nicle and chromium) determination was carried out using Atomic Absorption Spectrophotometer (SPECTRA A.A-55B, VARIAN, and Australia) as per standard methods.

\section{Characterization of soil}

\section{Soil sample collection}

Vegetables growing soil was collected $(0-30 \mathrm{~cm}$ depth) from the cultivation site in three distinct positions (as three replications) of the Horticulture research farm of BSMRAU, before the start of the experiment. Cow dung and compost were mixed with the experimental soil as required amount. This soil was poured into experimental plastic pots for cultivation. After harvesting of the cultivated crop, soil sample were also collected (0-30 $\mathrm{cm}$ depth) from every pot separately according to the treatments and kept into air tight polythene packet labeled with treatments to analysis the different parameters of soil after irrigation with TDW and GW. The samples were collected from the three distinct sites of each pot representing three replications of dataset. 


\section{Sample preparation and laboratory Analysis}

Soil samples were air-dried, grind and passed through a $2 \mathrm{~mm}$ size sieve. Then these samples were analyzed for evaluating the soil properties using standard methods.

\begin{tabular}{lll}
\hline Parameters & Method & Reference \\
\hline Soil pH & $\begin{array}{l}\text { Glass Electrode } \mathrm{pH} \text { Meter method with } \\
\text { soil water ratio 1:2.5 }\end{array}$ & {$[27]$} \\
Organic carbon & Wet Oxidation method & {$[28]$} \\
Phosphorus & Bray and Kurtz' method & {$[29]$} \\
Nitrogen & Kjeldahl method & {$[30]$} \\
Sulphur & Turbid metrically as barium sulfate & {$[31]$} \\
Zinc & AB-DTPA method & {$[32]$} \\
$\begin{array}{l}\text { Heavy metals } \\
\text { (iron, copper, } \\
\text { lead, cadmium, } \\
\text { nickel, chromium) }\end{array}$ & AAS -digestion code 309 & {$[33]$} \\
\hline
\end{tabular}

\section{Pot preparation for tomato cultivation}

Tomato (Solanum lycopersicum) seeds were collected from the Horticulture department and sown in the nursery of the same department. The plants were maintained with following the scientific ethics to avoid genetic resources claim. The Tomato seedlings at $28 \mathrm{~d}$ old were grown in the earthen pots by following randomized complete block design (RCBD) with three replications. Seventy two (72) pots of $27 \mathrm{~cm}$ diameter were filled with $10 \mathrm{~kg}$ of garden soil. Three pots of each treatment were assigned for growing 2 plants per plot and repeated for three times. Therefore, each experiment unit has 6 plants per treatment and triplicates samples were used for analyses to get average results. Fruits were harvested at the optimum maturity stage from all the treated pots and experiment continued up to 90 days, being enough to construe the maximum maturity which is known as days after transplanting (DAT) period. Tomato plant was irrigated with GW (control) and TDW ( 7 treatments) at 6 six days interval of the total growing durations with $1 \mathrm{~L}$ of water in each irrigation schedule. Thus, $15 \mathrm{~L}$ of each irrigation water treatment was used for watering these pots. The plant samples (morphological and fruit) were collected from three replications at each plot for each water treatment for data collection and further analyses. The experiment was conducted under the shed house for controlling the addition of rain water during cultivation period. 


\section{Growth and yield attributes of tomato}

\section{Plant height $(\mathrm{cm})$}

Plant height was measured by measuring tape from the tip of the root to the tip of the leaves of the plants. Measurement was taken from 4 randomly selected plants of a treatment from each replication and average values were calculated.

\section{No. of leaves per plant}

Leaves per plant were counted from 4 plants of each replication for every treatment and average was calculated at that time.

\section{Leaf length and width $(\mathrm{cm})$}

Leaf length and width was measured randomly in $\mathrm{cm}$ on 5 leaves by measuring scale from each plant. This measurement was taken from 4 plants of each treatment of each replication and average was calculated at the same time.

\section{Total no. of fruits}

Total no. of fruits per cluster appeared after pollination and final harvested fruits from the respective cluster were counted from 4 plants of each treatment and average was calculated at that time. These data were used to calculate the fruit abortion (\%) per treatment using the following formula-

Fruit abortion $(\%)=\frac{\text { Fruits per cluster after pollination-Fruits after final harvest }}{\text { Fruits per cluster after pollination }} \times 100$

\section{Fruit length and width (mm)}

Fruit length was measured randomly in $\mathrm{mm}$ on 5 fruits per treatment from each plant by digital slide calipers. Fruit diameter was measured from the previously selected same fruit samples in $\mathrm{mm}$ by digital slide calipers in the middle portion of the fruit. Measurement of randomly selected fruits was repeated 3 times from each treatment and average values were calculated.

\section{Yield per plant $(g)$}

Fruit yield per plant was calculated based on the individual fruit weight measured by the digital weighing scale. Individual fruit weight was taken from the selected 5 randomly selected fruits of 4 plants for each treatment and repeated for 3 times to make average.

\section{Biochemical analyses}

\section{Extract reparation for ascorbic acid estimation}


Ten (10) gram of sample was weighed and taken in a warring blender (MX-7985, National, Malaysia). The sample was homogenized with warring blender by adding $50 \mathrm{ml}$ distilled water. The homogenized solution was transferred into a $100 \mathrm{ml}$ volumetric flask and then centrifuged for 20 minutes at the speed of $4,000 \mathrm{rpm}$. The supernatant liquid was collected in the $100 \mathrm{ml}$ volumetric flask again. This was the extract solution for the determination of ascorbic acid.

\section{Amount of ascorbic acid in fruit (mg/100g)}

The ascorbic acid was determined as per the procedure described by Pleshkov [34]. Ten $\mathrm{ml}$ of the extract was taken in a conical flask. Then $5 \mathrm{ml}$ of $5 \% \mathrm{Kl}, 2 \mathrm{ml}$ of $2 \%$ starch solution, 2 $\mathrm{ml}$ of $100 \%$ glacial acetic acid were added to it and shaken vigorously. Finally, it was titrated with $0.001 \mathrm{~N}$ of $\mathrm{KIO} 3$ solutions from a burette till the permanent pink color appeared. The volume of $\mathrm{KIO} 3$ solution required for the titration was noted from the burette reading and free ascorbic acid content was quantified using the following formula:

Ascorbic acid content $(\mathrm{mg} / \mathrm{l00} \mathrm{g})=\frac{(F V 1 V 2)}{(V 3 W)} \times 100$

Where, $\mathrm{F}=0.088 \mathrm{mg}$ of Ascorbic Acid per $\mathrm{ml}$ of $0.001 \mathrm{~N} \mathrm{KIO}_{3}$

$\mathrm{V} 1=$ Titrated volume of $\mathrm{KIO}_{3} \mathrm{ml}$

$\mathrm{V} 2=$ Total volume of the sample extract $\mathrm{ml}$

V3 = Volume of the extract $(\mathrm{ml})$ taken for titration

$\mathrm{W}=$ Weight of the sample taken $(\mathrm{g})$

\section{Estimation of 6-carotene in fruit $(\mathrm{mg} / 100 \mathrm{~g})$}

One gram of sample was crushed thoroughly and mixed with $10 \mathrm{ml}$ acetone: hexane $(4: 6)$ solution. This sample was centrifuged and optical density of the supernatant was measured by double beam spectrophotometer (Model: APEL, UV- VIS Spectrophotometer, PD - 303 UV, PD 33-3-OMS-101 b, Japan) at $663 \mathrm{~nm}, 645 \mathrm{~nm}, 505 \mathrm{~nm}$ and $453 \mathrm{~nm}$. Calculation was done by the following formula [35].

$\beta$-Carotene $(\mathrm{mg} / \mathrm{l00} \mathrm{g})=$

$0.26($ OD663 $)+0.452($ OD453) $-1.22($ OD645) $-304($ OD505)

Where, bold figure indicates optimal density.

\section{Estimation of Chlorophyll $(\mathrm{mg} / \mathrm{g})$}

Chlorophyll was estimated on fresh weight basis by scratching the peel of the samples with $80 \%$ acetone by using Double Beam Spectrophotometer (Model: APEL, UV- VIS Spectrophotometer, PD - 303 UV, PD 33-3-OMS-101 b, Japan). Different chlorophylls were 
estimated using the following equations proposed by Witham et al. [36]. In brief, five mg peel of tomato was taken. The sample was dipped into $80 \%$ acetone in a test tube and the volume was made up to $25 \mathrm{ml}$. The test tube was covered with aluminum foil and the sample was kept over forty eight (48) hours in a dark place. Finally, the absorbance of the filtrate was taken by spectrophotometer at $663 \mathrm{~nm}$ and $645 \mathrm{~nm}$ respectively. The chlorophyll content of sample was calculated by the following formula:

Chlorophyll a $(\mathrm{mg} / \mathrm{g})=\frac{[12.7 \times(O D 663)-2.69(O D 645)] \times V}{W \times 1000}$

Chlorophyll b $(\mathrm{mg} / \mathrm{g})=\frac{[22.9 \times(O D 645)-4.68(O D 663)] \times V}{W \times 1000}$.

Chlorophyll total $(\mathrm{mg} / \mathrm{g})=\frac{[20.2 \times(O D 645)+8.02(O D 663)] \times V}{W \times 1000}$.

Where, $\mathrm{OD}_{645}=$ Optical density at $645 \mathrm{~nm}$ wave length, $\mathrm{OD}_{663}=$ Optical density at $663 \mathrm{~nm}$ wave length, $V=$ Volume of the extract, $\mathrm{W}=$ Fresh weight in grams of the tissue extracted

\section{Plant nutrient use efficiency (\%)}

Plant nutrient use efficiency (PNUE) depends on the plant's ability to take up nutrients efficiently from the soil, but also depends on internal transport, storage nature, root growth, root architecture, irrigation management and remobilization of nutrients. In the present study it has been assumed that the essential plant nutrients available in the $G W$ and TDW could be accumulated in the pot soil by the irrigation frequencies throughout the plant growing period. From these accumulated nutrients plant will uptake as per their requirement and might be expressed their growth and yield attributes and also bioaccumulated in different plant parts. The rest amount of nutrients might be left in the soil as residue. Therefore, PNUE was determined as per the procedure of Paul et al. [37] with some modifications by the following formula:

PNUE $(\%)=\frac{\text { Nutrient Toatal Supply-Nutrient Residue in Soil }}{\text { Nutrient Total Supply }} \times 100$

Where,

Nutrient Total Supply $=$ Total nutrient supply to the cultivated soil indicates the amount of nutrient supplied by 15 time irrigation frequencies with $1 \mathrm{~L}$ water of each irrigation + the amount of existing nutrient in the respective fresh soil before irrigation;

Nutrient Residue in Soil $=$ The residual amount of nutrient in the soil indicates the amount of nutrients remained in the cultivated soil that determined after subtracting the used amount of nutrient from the total supply of nutrient in the respective soil sample. [37]

\section{Enrichment factor (EF)}

The term enrichment factor depicts the degree of contamination of soil in terms of accumulation of heavy metal in the soil through irrigation wastewater in compare to the heavy metal in the uncontaminated soil [38]. The enrichment factor (EF) for heavy metals 
accumulated in tomato cultivated soil irrigated with different stages of TDW and GW was estimated by the following equation-

Enrichment Factor $(\mathrm{EF})=\frac{\text { Mean content of individual metal in soil of the WW irrigated pots }(\mathrm{Sm})}{\text { Mean content of individual metal in soil of the GW irrigated pots (Sc) }}$.

Where, Sm=Total supply of metal in the soil through irrigation wastewater + existing metal content in the soil before irrigation;

$\mathrm{Sc}=$ Total supply of metal in the soil through irrigation with ground water (control) + existing metal content in the soil before irrigation.

\section{Pollution load index (PLI)}

The degree of soil pollution load index for individual heavy metal was measured using the pollution load index (PLI) technique depending on soil metal concentrations exist for the specific duration of a crop. The following modified formula was used to measure the PLI in the tomato cultivated soils after crop harvest [39].

PLI $=\frac{\text { Concentration of heavy metal in WW irrigated soil remained as residue after cultivation }}{\text { Concentration of heavy metal available in the GW irrigated soil after cultivation }}$

\section{Sodium absorption ratio (SAR)}

The sodium absorption ratio (SAR) is commonly used as an index for evaluating the sodium hazard associated with an irrigation water supply [40]. The SAR is defined as the square root of the ratio of the $\mathrm{Na}$ to calcium+ magnesium $(\mathrm{Ca}+\mathrm{Mg})$. As different stages of TDW were used as irrigation treatment for tomato cultivation, therefore it is essential to sort out the sodium toxicity level of the TDW in compare with the GW for suitability justification of the TDW for vegetable cultivation. All cation measurements were expressed as milliequivalents per liter (meq/l). The SAR value was estimated as below-

Sodium Absorption Ratio (SAR) $=\frac{\mathrm{N} a^{+}}{\sqrt{\frac{1}{2}\left(C a^{2+}+M g^{2+}\right)}}$

\section{Statistical analyses}

The data recorded were analyzed statistically and expressed in terms of mean values of the three replications of each variable and standard errors. Two-way analysis of variance (ANOVA) was done for hypothesis test at $1 \%$ level of significance. HSD Tukey mean comparison post hoc test was performed for mean comparison among the irrigation treatments in relation to the significant dependent variables. Moreover, correlation matrix, cluster analysis and principal component analysis (PCA) was done in taking account of the all the dependent variables to find out the most effective and significant contributing characters for TDW irrigation evaluation in tomato cultivation. All the analysis was done with the help of R-program (version 4.1.2) using "agricolae", "ggplot2", "corrplot", "factominer", "factoextra" packages. 


\section{Results}

\section{Physiochemical properties of irrigation water}

\section{Physiological properties}

Various physiological properties of ground water and different stages of textile dyeing wastewater (TDW) were compared with irrigation water quality standard guidelines from various sources. All the water sources including ground water were significantly different in respect of physiological components. Different stages of TDW crossed the limit of total dissolved solids (TDS). The value was varied from 470 to $3320 \mathrm{mg} / \mathrm{L}$ in different wastewater samples, the highest value was from T8 followed by T4 $(2070 \mathrm{mg} / \mathrm{L})$. [41] stated that presence of high TDS in water makes it less suitable for irrigation. Interestingly, all other physiological components like $\mathrm{pH}$ (9.5), electric conductivity (EC), total suspended solids (TSS), biological oxygen demand (BOD), chemical oxygen demand (COD) were measured higher $(4200 \mu \mathrm{s} / \mathrm{cm}, 310,223,450 \mathrm{mg} / \mathrm{L})$ also in T8 which beyond the irrigation quality limit. Joshi and Santani [42] reported that high BOD reflects high concentrations of substances that can be biologically degraded, thereby consuming oxygen and potentially resulting in dissolved oxygen. High COD levels imply toxic condition and presence of biologically resistant organic substances [43]. Waste water T6 and T7 also crossed the limit of BOD, while T2 and T3 crossed the COD and T4 exceed the EC standard limit of irrigation. Moreover, dissolved oxygen (DO) was much lower (0.58) than irrigation quality only in T8 waste water. The lowest value of dissolved oxygen (DO) indicates the strong polluted water that is very harmful for biological phenomena. Although no standard limit was available, color value was the highest (1038 point-co-unit) also in T8 (Table 1).

\section{Plant nutrient properties}

All the plant nutrients except chloride was within the safe limit of irrigation quality. Chloride was seemed much higher in the treatments T8 and T4 (chronologically 2700 and 2500 $\mathrm{mg} / \mathrm{L}$ ), which might be due to the use of large amount of salt in dyeing process of cellulose with reactive dyes [4]. Solaimalai and Saravanakumar [44] reported that the use of poorquality wastewater with high EC and chloride has a negative influence on germination, root growth and subsequently in the absorption of water and nutrients.

\section{Heavy metal properties}

It has been reported that the major problem associated with textile processing effluents is the presence of heavy metal ions, which arise from material used in the dyeing process or in a considerably high amount, from metal containing dyes [45]. Heavy metals particularly copper (Cu), zinc ( $\mathrm{Zn})$ and iron (Fe) are widely used for the production of color pigments of textile dyes [46]. Copper ( $\mathrm{Cu})$, iron ( $\mathrm{Fe})$, lead $(\mathrm{Pb})$ and Zinc $(\mathrm{Zn})$, concentrations in all water sources were within the safe agricultural irrigation limit. Where concentrations were higher for first three in T8 $(0.11,0.731$ and $0.026 \mathrm{mg} / \mathrm{L})$ and for $\mathrm{Zn}$ in T4 $(0.914 \mathrm{mg} / \mathrm{L})$. In case of other heavy metals such as cadmium (Cd), nickel ( $\mathrm{Ni}$ ) and chromium $(\mathrm{Cr}) \mathrm{T} 8$ also exhibited the highest concentrations $(0.103,0.373$, and 0.329$)$ followed by $T 4<T 7<T 5$ and crossed agricultural standard. For most of the heavy metal concentrations, $\mathrm{T} 6<\mathrm{T} 3<\mathrm{T} 2$ waste water was under safe limit and contained lower values (Table 1). Earlier exhibited different textile 
dyeing waste water contained different physiochemical properties along with various plant nutrient elements in various concentrations which are essential for plant growth and development. So, using these waste water as an alternative irrigation water was attempted to better understand the benefits and risks.

\section{Fresh soil properties}

Soil that commonly used for the vegetable cultivation was selected and analyzed. Different physiochemical properties along with heavy metal concentration was checked before waste water being applied as a treatment in tomato cultivation. Physiochemical properties confirmed all the properties of the fresh soil were within the safe limit (Table 2). Adeyeye [47] reported that soil contamination by heavy metal may be as a result of top dressed-soil, whereas Nriagu [48] uttered no doubt that heavy metals are also present in soil naturally and non-degradable.

\section{Plant morphology as influenced by waste water irrigation}

\section{Plant height $(\mathrm{cm})$}

Growth was initially (up 30 DAT) better in ground water and T2 treated plant. Plant growth jumped in between 30-60 DAT and slowed down later. But widely fluctuated increased plant height was noticed in T6 treatment $(157.0 \mathrm{~cm})$, while slower rate of plant height was noted from T4 $(118.3 \mathrm{~cm}$ ) at the end of 90 DAT (Fig. 1). Higher amount of potassium and DO with lower heavy metal concentrations in $\mathrm{T} 6$ and lower plant nutrients with higher heavy metals along with $\mathrm{pH}, \mathrm{EC}, \mathrm{Cl}^{-}$in $\mathrm{T} 4$ might be the probable fact. Rodriguez et al. [49] reported decrease shoot and leaf length for less amount of dissolved oxygen. Long et al. [50] stated that excess chloride in growth media caused toxicity of crops and serious inhibition on plant growth.

\section{Number of leaves}

During active plant growing stage (up to $60 \mathrm{DAT}$ ), leaves production rate was slower and then production rate boosted up to 90 DAT. But T6 was extraordinary which increased leaves number continuously and produced the maximum leaves also (30.7). In reverse, slower rate noted from T4 (18.0) followed by T8 (19.0) at the end of 90 DAT (Fig. 2). Manivasakam [51] explained the capability of toxic elements present in effluent affected the plant metabolism, while Gazete [52] counted 7 leaves per plant when irrigated with high concentration of wastewater compare to the maximum leaves per (12) from the plants irrigated with deep tube well water.

\section{Yield and yield attributes as influenced by waste water irrigation}

\section{Fruit abortion (\%)}

As T8 and T4 waste water contained higher component of negative plant growth factor, fruit abortion was quite higher ( 86.1 and $84.2 \%$ ) compare to lowest abortion (53.6\%) in ground water treatment (Table 3). Khan [53] proved that soil contamination by industrial effluents including a variety of chemicals like heavy metals and phenolics, affected growth of plant. 
Through accumulation in living cells and decreased in cell activities it caused various deficiency or diseases subsequently inhibit the growth of plant.

\section{Fruit per plant}

Higher fruit abortion in T8 and T4 ultimately reflected in the lower fruit set per plant (15.3 and 16.3, accordingly). The highest fruit per plant was counted from ground water treated plant (34.0), which was statistically identical with T6 treated plant (30.7).

\section{Fruit length and width $(\mathrm{cm})$}

Fruit characteristics also represented imaging of previous phenomena where T8 (21.8 and $27.9 \mathrm{~cm}$, respectively) and T4 (24.1 and $27.1 \mathrm{~cm}$, respectively) waste water hampered the fruit growth. On the other hand, ground water treated plant (35.6 and 33.5) and T6 treated plant (35.0 and 34.2) were produced identically the largest fruit (Table 3).

\section{Fruit yield per plant (g)}

Higher number of fruits and larger sized fruits absolutely contributed the maximum yield per plant (Table 3). It was from T6 treated tomato plant $(565.6 \mathrm{~g})$ and was identical to ground water treated plant (520.5 g). For the vice-versa conditions, T8 and T4 treated plants handed the lowest yield per plant (197.8 and $235.2 \mathrm{~g}$, correspondingly). Higher heavy metals along with higher TDS, color point, EC, BOD, $\mathrm{Cl}^{-}$might adversely affected the productivity, yield and yield attributes [54]. Ahmad et al. [55] also reported that higher concentration of heavy metals in wastewater are potent regarding plant growth and development and adversely affect the yield.

\section{Physiochemical attributes as influenced waste water irrigation}

\section{Chlorophyll $a$ and chlorophyll b $(\mathrm{mg} / 100 \mathrm{~g})$}

Chlorophyll a $(0.83 \mathrm{mg} / 100 \mathrm{~g})$ and chlorophyll b $(0.34 \mathrm{mg} / 100 \mathrm{~g})$ content in T6 treated waste water tomato fruit were much higher compare to other treatments except ground water. Chlorophyll content $(0.12$ and $0.06 \mathrm{mg} / 100 \mathrm{~g}$, respectively) was the lowest in mixed effluent treated (T8) tomato fruit which was followed by T4 treated tomato (Table 4).

\section{6 carotene and ascorbic acid ( $\mathrm{mg} / 100 \mathrm{~g})$}

Similar to chlorophyll content, higher concentrated heavy metal also restricted the formation and accumulation in tomato fruits. As a consequence, the lowest values were from T8 treated fruit ( 0.001 and $5.07 \mathrm{mg} / 100 \mathrm{~g}$, correspondingly) followed by T4 waste water treatment. Nevertheless, the highest $\beta$ carotene $(0.038 \mathrm{mg} / 100 \mathrm{~g})$ and ascorbic acid $(11.04 \mathrm{mg} / 100 \mathrm{~g}$ ) were measured in T6 treated tomato fruits (Table 4). Hossain et al. [56] stated that textile effluents with heavy metals caused a reduction in parameters like chlorophyll content, $\beta$-carotene and ascorbic acid. 


\section{Total supply and utilization of plant nutrients}

$\mathrm{N}, \mathrm{P}, \mathrm{K}, \mathrm{S}$ are essential plant nutrients for the growth, yield and physiochemical attributes. Total supply and percent use of these nutrients from the ground water and different stages of textile dyeing waste water were determined to better understand the intention of plant growth (Table 5). Although ground water (T1) irrigated plant received highest N (2963 mg), but use efficiency was lowest $(99.5 \%)$ while the highest $\mathrm{N}$ use efficiency $(99.7 \%)$ was from the T6 treated plants. In case of $\mathrm{P}$ and $\mathrm{K}$ both the supply (9876 and $123.9 \mathrm{mg}$ ) and use efficiency (98.1 and 88.8, respectively) were the highest also in the T6 waste water. Conversely, the lowest use efficiency of $\mathrm{P}$ and $\mathrm{K}(97.5$ and $43.8 \%)$ was in the T8 treatment. Although T8 treated provided the highest S (1030.1 mg) supply but contributed the lowest use efficiency (44.8) followed by T4 waste water treatment. As a reason of comparatively higher supply and use efficiency of N, P and K by T6 waste water resulted better growth, development and yield of tomato. Due to reverse situation of PKS use efficiency, T8 orT4 provided poor performances of tomato plant.

\section{Enrichment factor (EF) and pollution load index (PLI)}

Keep in mind the positive and negative growth pattern of tomato, other components related to heavy metals were investigated for environmental issues of soil (Table 6). Enrichment factor was the highest in T8 waste water for six out of seven heavy metals (Fe, $\mathrm{Cu}, \mathrm{Pb}, \mathrm{Cd}, \mathrm{Ni}$ and $\mathrm{Cr}$ ). Whereas, EF of $\mathrm{Zn}$ was the highest from T4 waste water. However, T8 waste water also possess the highest pollution load index (PLI) for three out of seven heavy metals ( $\mathrm{Fe}, \mathrm{Cu}, \mathrm{Zn}$ ) and possess the lowest PLI for $\mathrm{Cd}$ and Ni. Meanwhile, the highest PLI for $\mathrm{Pb}$ was from $\mathrm{T} 7$, for $\mathrm{Cd}$ was from $\mathrm{T} 5$ and for $\mathrm{Cr}$ was from T4 waste water. Waste water treatment T6, T2 and T3 were not involved in the highest EF and PLI contributor. In contrary, the lowest EF and PLI were counted mostly from T3 and either from T2 or T6. Therefore, these three waste water treatments may be safe for soil environment and plant growth up to some extent.

\section{Sodium absorption ratio (SAR)}

For further exploration of soil and plant growth issues, SAR from soil residue was measured after irrigated with waste water (Table 7). Results indicated that concentration of $\mathrm{Na}^{+}$and $\mathrm{Ca}^{2+}$ were the highest in T8 waste water treated soil. Waste water T4 treated soil was the $2^{\text {nd }}$ highest., while T7 treated soil was the $3^{\text {rd }}$ highest. Inversely, T8, T4 and T7 exposed chronologically the $1^{\text {st }}, 2^{\text {nd }}$ and $3^{\text {rd }}$ lowest $\mathrm{Mg}^{2+}$ content. These ultimately increased the SAR values of T8, T4 and T7 treated soil (21.46, 10.10 and 4.60, correspondingly) and turned the fresh soil into "severe" or "slight to moderate" categorized saline soil. Other waste water treated soil did not transformed soil to salinity too much. Other waste water especially T2, T3 and T6 might be safe for crop production up to some extent.

\section{Correlation matrix and cluster analysis}

Correlation matrix between the variables (Fig. 2a) showed moderate to strong positive and negative relationships with one or more variables such as enrichment factor (EF) and 
pollution load index (PLI) of heavy metals (except $\mathrm{Cd}$ and $\mathrm{Ni}$ ) were positively correlated with fruit abortion and SAR, while were negative with yield. Moreover, NPKS use efficiency (UE) were negative with fruit abortion and SAR, while were positive with yield. Based on the correlation there were three main clusters were formed with the distinct deviations from each other (Figure 2b). Cluster-I includes the variables of PLINi, Yield, SUE, KUE, PLICd; cluster-II grouped EFCu, NUE, PUE and the cluster-III includes the rest of the total variables of 21 as indicated: PLICu, PLIZn, EFFE, EFPb, PLIPb, PLICr, Fruit abortion, EFZn, SAR, PLIFe, EFCd, EFNi and EFCr. From these clusters it has been revealed that plant nutrients, yield variables are clearly distinguished than that of the heavy metals enriched and polluted variables (Fig. 2b).

\section{PCA of TDW irrigated soil data}

Multivariate principal component analysis (PCA) employed to depict the relationship and impact of TDW wastewater irrigation on soil plant nutrient efficiency (PNUE); degree of pollution with heavy metals (HMs) by pollution load index (PLI) and tomato yield cultivated on those soils with precise evaluation of the large variables. PCA allowed us to deduce how certain variables were interconnected with each other to categories the TDWs after generating two significant PCs (Dim1 and Dim2) with total explained variance of $71.5 \%$ using the 21 variables (Fig. 3a and 3b). From the variables-PCA plot, it has been seen that the first PC1 (Dim1) explained $55.8 \%$ contribution of total variables with positive loading on the PLIcu, PLIZn, EFFe, EFPb, PLIPb, SAR, EFNi, EFCd, EFCr, Fruit abortion, EFZn and PLICr. Meanwhile, the original variability of $15.7 \%$ was explained by PC2 (Dim2) with the positive loading on SUE (Fig. 3a).

A PCA-Biplot of PC1 vs PC2 (Dim1 vs Dim2) drawn as vectors showed that seven stages of TDW and GW occupy different region of the plots with well-defined patterns (Fig. 3b). Biplot simultaneously represent both the observations and the variables with a specific direction along with the PC axis. The direction of the variable arrows indicates the direction in which concentration of the corresponding variables increases most, and the length of the arrows equals the rate of change in that direction. The clustering of irrigation water indicated the significant impact of TDW irrigation on the yield; fruit abortion of tomato with negative correlation while grown in the heavy metals enriched and polluted soil. Among the TDW stages T8, T4, T7 distinctly fell into the opposite direction to the T2, T3, T5 and T6 of the PC1. Considering the PC2, soils from the T8 and T4 irrigated pot, were grouped in opposite side and mainly due to the highest concentrations of $\mathrm{Cu}, \mathrm{Zn}, \mathrm{Fe}, \mathrm{Pb}$ in $\mathrm{T} 8$ and $\mathrm{Cd}, \mathrm{Ni}, \mathrm{Cr}$ in T4. Regarding the EF and PLI of HMs variables, most of the EF and PLI were closely grouped together and associated with the cluster of T8, T7 and T4. Besides, T2, T3, T5 and T6 were weakly clustered with SUE, PLICd, KUE. This could be explained by the physiochemical evidence of the T4 and T8 stages of TDW, where sharp increase of heavy metals was found and that could be accumulated in the irrigated soil to cause increase EF and PLI than the other TDW. Furthermore, soils samples from the GW (control), with the lowest content of heavy metals, were grouped in the negative side of the PC1 and positive side of the PC2, revealed the reduce influence of the heavy metals on the GW irrigated soil. 


\section{Discussion}

Soil collected for the study was naturally in good physiochemical properties for crop production having quality $\mathrm{pH}, \mathrm{CEC}, \mathrm{EC}$, macronutrients and micronutrients as well as heavy metals (Table 2). Natural process of mineralization, use of different manures, fertilizers and pesticides along with different sources of irrigation water probably the reason behind. For example, due to high mobility excess NO3-N accumulated in the soil root zone $[57,58]$. Impurity of phosphate rocks and heavy phosphatic fertilization over years, $\mathrm{Cd}$ accumulating in soils and becoming more and more toxic $[59,60]$. Furthermore, Fertilizers such as NPK, phosphate, sulphate $(\mathrm{Cu}, \mathrm{Fe})$ and animal manures commonly amend $\mathrm{Hg}, \mathrm{Cd}, \mathrm{Ni}, \mathrm{Zn}$ and $\mathrm{Cd}$ into soil $[61,62]$. An excessive accumulation of trace metals such as $\mathrm{Cd}, \mathrm{Cr}, \mathrm{Cu}, \mathrm{Fe}, \mathrm{Mn}, \mathrm{Pb}$ and $\mathrm{Zn}$, in the soils through irrigation [63] or effluent [18] creates problems which leads to metal uptake by crops affecting food quality and safety [64]. Hamilton et al. [65] mentioned the strong sorbs of $\mathrm{Cr}$ in the soil at neutral $\mathrm{pH}$, while alkaline soil reduced the bioavailability of $\mathrm{Zn}$ in the soil.

Due to increasing demand of crop production for the geometric world population, scarcity of ground water made bund to irrigate crops with different sources especially with waste water (WW) from industrial and non-industrial sources. As WW provides different plant nutrients along with organic matter which are helpful for the fertility and productivity of soil [66-68], farmers indeed prefer to reduce chemical fertilizer and net input cost [19]. Despite of economic benefits, WW has both positive and negative potential impacts on agricultural crop production, public health, soil resources and ecosystems [19, 20]. Effluent treatment plant (EFT) in textile industries may solve the negative issues, but reluctance of concerned industries problems never elucidates due to pricey EFT. Concerning expensive EFT, scarcity of irrigation water and benefit and risk derived from WW, water samples were collected from seven different stages of textile dyeing process before being released for ETP. Affirmative consequence in crop production and soil environment of some stages of textile WW, may reduce the ETP as well net input cost of crop production and environment hazards $[11,15]$. Physiochemical properties along with heavy metal contents of seven stages WW were analyzed for different component concentrations. In where, T8 crossed the limit of agricultural standard for almost all physiological parameters such as TDS, TSS, EC, BOD, COD affording the highest value. T8 also delivered the highest $\mathrm{Cl}^{-}$and heavy metals like Cd, $\mathrm{Ni}, \mathrm{Cr}$; but other heavy metals having higher value such as $\mathrm{Cu}, \mathrm{Fe}, \mathrm{Pb}$ and $\mathrm{Zn}$ along with plant nutrients were within the safe limit. Chronologically $T 4<T 7<T 5$ also crossed the agricultural limit standard for heavy metals like T8 trend, but also offered plant nutrients safely. Meanwhile, $\mathrm{T} 6<\mathrm{T} 3<\mathrm{T} 2$ chronologically delivered the lower values in respect of most heavy metals and also provided good amount of plant nutrients alike fresh ground water (T1). Long term use of these WW to good agricultural soil were validated in tomato cultivation.

One liter of WW was applied each time at six days interval during tomato crop cultivation up to three months. Plant height, leaf number, fruit abortion percent, fruit per plant, fruit length and width, yield per plant, chlorophyll, $\beta$ carotene and ascorbic acid content were hampered either in T8 (mixed effluent) or followed by T4 ( $2^{\text {nd }}$ wash after bath drain) WW, while T6 ( $2^{\text {nd }}$ wash after soaping) exhibited the best performances. These poor exhibition by T8 and T4 might be due to the excess concentrations of physical and heavy metal components. Lellis et al. [69] stated that textile dyes significantly negotiate the water aesthetic quality with increased BOD and COD which impair photosynthesis and inhibit plant 
growth, enter the food chain, provide recalcitrance and bioaccumulation, and may promote toxicity, mutagenicity and carcinogenicity. Goel [70] reported the higher EC as an indicator of excess salinity that restricts water potentiality of the soil and impact on crop physiology and yield. On the other hand, Joshi et al. [71] revealed that the higher concentration of $\mathrm{Cr}$ seriously reduced leaf chlorophyll, root, and shoot length. Whereas, the high level of $\mathrm{Cd}$ reflected visible symptoms of injury in terms of chlorosis, growth inhibition, browning of root tips and finally death [72]. For these reasons, use efficiency of PKS plant nutrient components were lower in T8 followed by T4. Comparatively higher supplier and user efficacy of NPK, T6 impact on better growth, yield and yield attributes.

Enrichment factor (EF) expressed proportionately higher supplier of heavy metals to the plant, while pollution load index (PLI) mentioned higher provider of soil pollution. Here, higher EF with lower PLI mentioned the higher solubility and bioavailability for the plant, while higher EF with higher PLI indicated the lower bioavailability to the plant and deposited in soil. T8 enriched (EF) supply of heavy metals to the plant (except Zn), while T4 enriched Zn to tomato plant after applying 15-liter WW during the experimental period. PLI of Fe, Cu and $\mathrm{Zn}$ into the soil were the highest from T8 indicated higher deposition into soil. Contrarywise, the lowest PLI of $\mathrm{Cd}$ and $\mathrm{Ni}$ were also from T8 indicated higher solubility and bioavailability to the plant. Cd was easily absorbed by plants $[65,73]$ and most moveable metals which moved within organism by active ion pumps that normally transport $\mathrm{Ca}^{2+}$ [74]. Moreover, the highest PLI for Pb was from 77 followed by $\mathrm{T} 8$ at higher concentration, while for $\mathrm{Cd}$ was from $\mathrm{T} 5$ at lower concentration specified indicated lower bioavailability of $\mathrm{Pb}$ than $\mathrm{Cd}$ [7577]. PLI of $\mathrm{Cr}$ was the highest from T4 followed by T8 WW that expressed their higher deposition into soil. Hamilton et al. [65] indicated that $\mathrm{Cr}$ is less soluble in water and retained in the soil, while $\mathrm{Ni}$ sorbs loosely and more soluble in the soil solution. Copaciu et al. [78] exposed that $\mathrm{Cr}$ from textile dye provided oxidative stress which is another problem associated with recalcitrant character, offering a considerable damage to the growth and development of plants, especially to photosynthesis and $\mathrm{CO}_{2}$ assimilation. Concentration of $\mathrm{Na}^{+}$and $\mathrm{Ca}^{2+}$ were in descending order from $\mathrm{T} 8<\mathrm{T} 4<\mathrm{T} 7$, while respected to $\mathrm{Mg}^{2+}$ content these were the $1^{\text {st }}, 2^{\text {nd }}$ and $3^{\text {rd }}$ lowest. Which subsequently turned the fresh soil into "sever" or "slight to moderate" categorized saline soil.

Correlation matrix of different variables clearly explained that plant nutrients UE were positively related to yield and negative to fruit abortion and SAR. EF and PLI of heavy metals demonstrated hampered yield and increased SAR with few exceptions in Cd and Ni. Cluster-I included the variables of PLINi, Yield, SUE, KUE, PLICd. Principal component analysis (PCA) also indicated same variables as major contributors of yield while irrigated with T1, T2, T3 and T6 WW. In opposition, EFFe, EFPb, EFZn, EFCd, EFCr, EFNi and other PLI were indicated as major contributors of fruit abortion and SAR when irrigated with T8, T4 and T7 WW mainly.

\section{Conclusion}

Among the studied TDW stages, T6 ( $2^{\text {nd }}$ wash after soaping) was afforded better growth and yield of tomato with better nutrient use efficiency. In addition, Stages T3 (enzyme treated water), T2 ( $2^{\text {nd }}$ wash after scoring and bleaching) and T6 were provided comparatively lower EF and PLI alike T1 (ground water) for heavy metals which did not transform the SAR of soil for salinity. In contrary, stages $\mathrm{T} 8<\mathrm{T} 4<\mathrm{T} 7$ chronologically afforded higher EF and PLI for 
heavy metals and transformed soil into "severe" and "slight to moderate" saline with the increased SAR. Correlation matrix and PCA were demonstrated that heavy metals (except Cd and $\mathrm{Ni}$ ) negatively correlated in the yield of tomato, while positive to fruit abortion and SAR. Therefore, WW stages T2, T3 and T6 from textile dyeing could be released directly to agricultural crop production instead of ETP as to benefitted economically both farmers and industrialists. Application of these stages to other vegetable crops along with heavy metals distribution to different plant parts are desired for further studies.

\section{Declaration on plant handling with the relevant guidelines and regulations}

Tomato (Solanum lycopersicum) was used as plant material in the present study. It has been declared that the tomato seeds were collected from the department of Horticulture, Bangabandhu Sheikh Mujibur Rahman Agricultural University, Gazipur-1706, Bangladesh. The tomato seeds are producing and preserving in the Horticulture department for using in the research purposes. The field study was conducted in the nursery of the same department with following standard procedures of cultivation and without violating the relevant guidelines and regulations of the plant handling process.

\section{References}

1. FAO, (Food and Agriculture Organization). 2000. Using Water Efficiently: Ideas for Communities. Available at http://www.fao.gov/WaterSense/docs/community508.pdf

2. Connor, R., Faurès, J.M., Kuylenstierna, .J, Margat, .J, Steduto P., Vallée, D., van der Hoek, W. 2009. Evolution of water use. The United Nations World Water Development Report 3: Water in a Changing World. UNESCO Publishing, London.

3. BKMEA. 2012. Bangladesh Knitwear Manufacturers \& Exporters Association Membership profile.

4. Allegre, C., Moulin, P., Maisseu, M., Charbit, F. 2006.Treatment and reuse of reactive dyeing effluents.Journal of Membrane Science, 269, 15-34.

5. Reife, A. 1993. Dyes, environmental chemistry. In: kirk-Other Encyclopedia of Chemical Technology. John Wiley \& Sons, Inc., New York, pp.753-784.

6. Smith, H.M. 1996. US safety, health, and environmental regulatory affairs for dyes and pigments. In: Reife, A., Freeman, H.S., Environmental Chemistry of Dyes and pigments. John Wiley \& Sons, Inc., Canada, pp. 295-306.

7. Bedbabis, S., Ferrara, G., Ben Rouina, B., Boukhris, M. 2010. Effects of irrigation with treated wastewater on olive tree growth, yield and leaf mineral elements at short term. Sci. Hortic., 126, 345-350.

8. Paranychianakis, N.V., Nikolantonakis, M., Spanakis, Y., Angelakis, A.N. 2006. The effect of recycled water on the nutrient status of Soultanina grapevines grafted on different rootstocks. Agric. Water Manage., 81 (1), 185-198

9. Kiziloglu, F. M., Turan, M., Sahin, U., Kuslu, Y., Dursun, A. 2008. Effects of untreated and treated wastewater irrigation on some chemical properties of cauliflower (Brassica 
olerecea L. var. botrytis) and red cabbage (Brassica olerecea L. var. rubra) grown on calcareous soil in Turkey. Agricultural Water Management, 95, 716-724.

10. Emongor, V. E., Ramolemana, G. M. 2004.Treated sewage effluent (water) potential to be used for horticultural production in Botswana.Physics and Chemistry of the Earth, 29,1101-1108.

11. Pereira, B.F.F., He, Z.L., Stoffella, P.J. Melfi, A.J. 2011. Reclaimed wastewater: Effects on citrus nutrition. Agricultural Water Management, 98, 1828- 1833.

12. Sousa, G., Fangueiro, D., Duarte, E., Vasconcelos, E. 2011. Reuse of treated wastewater and sewage sludge for fertilization and irrigation. Water Science \& Technology, 64(4), 871-879.

13. Mapanda, F., Mangwayana, E. N., Nyamangara, J., Giller, K. E. 2005. The effect of longterm irrigation using wastewater on heavy metal contents of soils under vegetables in Harare, Zimbabwe. Agriculture, Ecosystems and Environment, 107, 151-165.

14. Letshwenyo, M. W., Mokokwe, G. 2020. Accumulation of heavy metals and bacteriological indicators in spinach irrigated with further treated secondary wastewater. https://doi.org/10.1016/j.heliyon.2020.e05241

15. Aiello, R., Cirelli, G. L., Consoli, S. 2007. Effects of reclaimed wastewater irrigation on soil and tomato fruits: A case study in Sicily (Italy). Agricultural Water Management, 93 (12), 65-72. https://doi.org/10.1016/j.agwat.2007.06.008

16. Qadir, M., Wichnels, D., Raschid-Sally, L., Singh Minhas, P., Drechsel, P., Bahri, A., McCornick, P. 2007. Agricultural use of marginal-quality water-opportunities and challenges. In: Molden, D. (Ed.), Water for Food; Water for Life. A Comprehensive Assessment of Water Management in Agriculture. Earthscan, 8-12 Camden High Street, London, pp. 425-457.

17. Pedrero, F., Kalavrouziotis, I., Alarcón, J.J., Koukoulakis, P., Asano, T. 2010. Use of treated municipal wastewater in irrigated agriculture-Review of some practices in Spain and Greece. Agric. Water Manage. 97, 1233-1241.

18. Anwar, S., Nawaz, M.F., Gul, S., Rizwan, M., Ali, S., Kareem, A. 2016. Uptake and distribution of minerals and heavy metals in commonly grown leafy vegetable species irrigated with sewage water. Environ. Monit. Assess., 188.

19. Hussain, I., Raschid, L., Hanjra, M.A., Marikar, F., van der Hoek, W. 2002. Wastewater use in agriculture: review of impacts and methodological issues in valuing impacts. Working Paper 37. International Water Management Institute, Colombo in contaminated soils and food crops irrigated with wastewater in Beijing, China. Environ. Pollut., 152, 686692.

20. Scott, C. A., Faruqui, N. I., Raschid-Sally, L. 2004. Wastewater Use in Irrigated Agriculture: Confronting the Livelihood and Environmental Realities

21. De Miguel, E., Jimenez de Grado, M., Llamas, J. F., Martin-Dorado, A. 1998. The overlooked contribution of compost application to the trace element load in the urban soil of Madrid (Spain). The Science of the Total Environment, 215, 113-122.

22. Mielke, H. W., Gonzales, C. R., Smith, M. K., Mielke, P. W. 1999. The urban environment and children health: soils as an integrator of lead, zinc and cadmium in New Orleans, Louisiana, USA. Environmental Research, 81, 117-129.

23. Madrid, L., Diaz-Barrientos, E., Madrid, F. 2002. Distribution of heavy metals contents of urban soils in parks of Seville. Chemosphere, 49, 1301-1308.

24. Agrafioti, E., Diamadopoulos, E. 2012. A strategic plan for reuse of treated municipal wastewater for crop irrigation on the Island of Crete. Agric. Water Manage., 105, 57-64. 
25. Stone, M. A., \& Taylor, L. T. (2000). SFE-GC with quantitative transfer of the extraction effluent to a megabore capillary column. Analytical chemistry, 72(14), 3085-3092.

26. APHA, AWWA and WEF. 1998. Standard Method for the Examination of Water and Wastewater, $20^{\text {th }}$ Edition. American Public Health Association (APHA)/ American water works Association (AWWA)/ Water Environment Federation (WEF). Washington, USA.

27. McLean, E.O. 1982. Soil pH and lime requirement. In: Page, A. L., R. H. Miller and D. R. Keeney (eds.) Methods of soil analysis. Part 2 - Chemical and microbiological properties. (2nd Ed.). Agronomy, 9:199-223.

28. Nelson, D.W., Sommers, L.E. 1982. Total carbon, organic carbon, and organic matter. Methods of Soil Analysis, part 2. ASA 9, $2^{\text {nd }}$ edition.

29. Olsen, S.R., Sommers, L.E. 1982. Phosphorus. 403-430 pp. In: A. L. Pageetal.(eds.) Methods of soil analysis, part2. Agron. Mongr.9. 2nd ed. ASA and SSSA, Madison, WI.

30. Bremner, J.M., Mulvaney, C.S. 1982. Total nitrogen. In: Methods of soil analysis, Part2, Chemical and microbiologicalproperties, (eds.) A. L. Page, R. H. Miller and D. R. Keeny, American Society of Agronomy and Soil Science Society of America, Inc., Madison, Wisconsin, USA., 595-624 pp.

31. Chesin, L., Yien, C.H. 1951. Turbidimetric determination of available sulfates. Soil Sci. Soc. Am. Proc., 15: 149-151.

32. Lindsay,W.L., Norvall, W.A. 1978. Development of a DTPA micronutrient soil test for zinc, iron, manganese and copper. Soil Science Society of American Journal, 42:421-428.

33. Milestone.2006. Application Note for Food and Feed. Sorisole. Italy

34. Pleshkov, B. P. 1976. Practical Work on Plant Biochemistry.Mosco.Kolos, Pp : 236-238.

35. Nagata, M. K. Yamashita, D. I. 1992. Simple method for simultaneous determination of Chlorophyll and Carotenoids in tomato. J. Japan Soc. Hort. Sci. 61(2): 686-687 687. (Supplementary issue).

36. Witham, H., Blades, D. F., Devin, R. H. 1986. Exercise in Plant physiology ( $2^{\text {nd }}$ edition), PW Publishers, Boston, USA., pp. $128-131$.

37. Paul, E. F., Tom, B., Frank, B., Fernando, G. 2015. Nutrient/fertilizer use efficiency: Measurement, current situation and trends. In Chapter: 1 (pp. 1-26). US: International Plant Nutrition Institute.

38. Hussain, A., Priyadarshi, M., Dubey, S. 2019. Experimental study on accumulation of heavy metals in vegetables irrigated with treated wastewater. Applied Water Science, 9, 122

39. Liu, W.H., Zhao, J.Z., Ouyang, Z.Y., Soderlund, L., Liu, G. H. 2005. Impacts of sewage irrigation on heavy metals distribution and contamination in Beijing, China. Environment International, 31, 805-812. doi:10.1016/j.envint.2005.05.042

40. Rajendran Prasad, D. S., Sadashivaiah, C., Rangnna, G. 2009. Health risk assessment of heavy metals for population via consumption of vegetables. World Applied Sciences Journal, 6 (12), 1602-1606.

41. Kannan, N., and Thavamani, K. 1993. Assessment of industrial ground water pollution potential from correlation of parametric ratio-Dye industry. Indian journal of Environment protection. 13(5), 345-348.

42. Joshi, V.J., Santani, D.D. 2012. Physicochemical Characterization and Heavy Metal Concentration in Effluent of Textile Industry. Universal Journal of Environmental Research and Technology. 2 (2), 93-96.

43. Sawyer, C.C., and McCarty, P.L. 1998.Chemistry for Environmental Engineers, McGraw Hill, NewYork. pp 331-514. 
44. Solaimalai, A., Saravanakumar, R. 2004. Assessment of irrigation water qualities, In water pollution assessment and management, Daya publishing house, New Delhi, 389395.

45. Correia, V.M. 1998. Sulfonated surfactants and related compounds: Facet of their desulfonation by aerobic and anaerobic bacteria. Tenside Surfactants Detergents, 35, 52-56.

46. Halimoon, N., Goh, R. S. Y. 2010. Removal of Heavy Metals from Textile Wastewater using Zeolite. Environment Asia. 3(special issue), 124-130, ISSN 1906-1714.

47. Adeyeye, E.I. 2005. Trace metals in soils and plants from Fadama farms in Ekiti state, Nigeria. Bulletin of Chemical Society of Ethiopia, 19, 23-24. Agro Environment and Development, 4, 18-19.

48. Nriagu, J.O.1990. Global metal pollution: Poisoning the biosphere. Environment Envtar, 32(9), 7-11, 28-33.

49. Rodriguez, A., Mosquera Losada, M.R., GaticaTrabanini, E. 2000. Pasture production and tree growth in a young pine plantation fertilized with inorganic fertilizers and milk sewage in northwestern Spain. Agroforestry Systems, 48: 245-256.

50. Long, X.X., Yang, X.E., Ni, W.Z., Ye, Z.Q., He, Z.L., Calvert, D.V., Stoffella, J.P. 2003. Assessing zinc thresholds for phytotoxicity and potential dietary toxicity in selected vegetable crops. Comm. Soil Sci. Plant Anal, 34, 1421-1434.

51. Manivasakam, N. 2003. Industrial effluents origin, characteristics, effects, analysis and treatment. Sakthi publications, Coimbatore.

52. Gazete, R. 2001. ToprakKirliliUiKontrol. Y.netmeliUi. No: 24609, Ankara.

53. Khan, H.R. 2006. Assessment of SPWAC (Soil-Plant-Water-Air continuum) Quality within and around Dhaka City. Report submitted to the Director of the centre for Advanced Studies and Research in Biotechnological Sciences, University of Dhaka, Bangladesh.

54. Yadav, R.K., Goyal, B., Sharma, R.K., Dubey, S.K. Minhas, P.S. 2002. Post-irrigation impact of domestic sewage wastewater on composition of soils, crops and ground water-a case study. Environment International, 28, 481-486.

55. Ahmad, K., Ejaz, A., Azam, M., Khan, Z.I., Ashraf, M., Al-Quarainy, Fardous, A. 2011. Lead, cadium and chromium contents of canola irrigated with sewage water. Pak Journal of Botany, 43(2):1403-1410.

56. Hossain, F., Malik, S.A., Athar, M., Bashir, N.,Younis, U., Hassan, M.U. 2010. Effect of tannery effluent on seed germination and growth of two sunflower cultivars. African Journal of Biotechnology, 9(32):5113-5120.

57. Yuan, X.M., Tong, Y.A., Yang, X.Y., Li, X.L., Zhang, F.S. 2000. Effect of organic manure on soil nitrate nitrogen accumulation. Soil Environment Science, 9, 197-200.

58. Shamrukh, M., Corapcioglu, M., Hassona, F. 2001. Modeling the effect of chemical fertilizers on ground water quality in the Nile Valley Aquifer, Egypt. Groundwater, 39 (1), 59-67.

59. Ahmed, J.U., Goni, M.A. 2010. Heavy metal contamination in water, soil, and vegetables of the industrial areas in Dhaka, Bangladesh. Environ Monit. Assess, 166:347-357.

60. Alam, M. G. M., Snow, E. T. Tanaka, A. 2003. Arsenic and heavy metals concentration of vegetables grown in Samta village, Bangladesh. The Science of the Total Environment, 111, 811-815.

61. Lente, I., Keraita, B., Drechsel, P., Ofosu-Anim, J., Brimah, A.K. 2012. Risk assessment of heavy-metal contamination on vegetables grown in long-term wastewater irrigated urban farming sites in Accra, Ghana. Water Qual. Expo. Health, 4, 179186. 
62. Alloway, B.J. 2013. Sources of heavy metals and metalloids in soils. Heavy metals in soils. In: Alloway, B.J. (Ed.), Trace Metals and Metalloids in Soils and Their Bioavailability, third ed. Springer, pp. 1150.

63. Singh, S., and Kumar, M. 2006. Heavy metal load of soil, water and vegetables in periurban Delhi. Environmental Mornitoring and Assesment, 120: 79-91.

64. Khan, S., Cao, Q., Zheng, Y.M., Huang, Y.Z., Zhu, Y.G. 2008. Health risks of heavy metals

65. Hamilton, A.J., Stagnitti, F., Xiong, X., Kreidl, S., Benke, K.K., Maher, P., 2007. Wastewater irrigation: state of play. Vadose Zone Journal, $6,823840$.

66. Meli, S., Porto, M., Belligno, A., Bufo, S.A., Mazzatura, A., Scopa, A. 2002. Influence of irrigation with lagooned urban wastewater on chemical and microbiological soil parameters in a citrus orchard under Mediterranean condition. Sci. Total Environment, 285, 69-77.

67. Rusan, M.J.M., Hinnawi, S., Rousan, L. 2007. Long term effect of wastewater irrigation of forage crops on soil and plant quality parameters. Desalination, 215, 143-152.

68. Vergine, P., Lonigro, A., Salerno, C., Rubino, P., Berardi, G., Pollice, A. 2017. Nutrient recovery and crop yield enhancement in irrigation with reclaimed wastewater: a case study. Urban Water Journal, 14, 325-330.

69. Lellis, B., Favaro-Polonio, C. Z., Pamphile, J. A., Polonio, J. C. 2019. Effects of textile dyes on health and the environment and bioremediation potential of living organisms. Biotechnology Research and Innovation, 3, 275-290. https://doi.org/10.1016/j.biori.2019.09.001

70. Goel, P. K. 2006. Water Pollution: Causes, Effects and Control, 2nd Edition. New Age International Publisher, New Delhi.

71. Joshi, U. N.; Rathore, S. S. and Arora, S. K. 1999. Effect of chromium on growth and development of cow pea. Indian Journal of environ. Prot., 19(10): 157-162.

72. Guo, J., Dai, X., Xu, W., Ma, M. 2008. Over expressing GSHI and AsPCSI simultaneously increases the tolerance and accumulation of cadmium and arsenic in Arabidopsis thaliana. Chemosphere, 72: 1020-1026.

73. Sheng, P. H., Zhou, A. X., Li, P. J. 2001. Pollution Ecology. Science Press, Beijing.

74. Berge, H., Kiibus, M., Kautsky, N. 1995. Heavy metals in tropical Kariba, Zimbabwe. Water, Air and Soil Pollution, 83, 237-252.

75. Gupta, S., Satpati, S., Nayek, S., Garai, D. 2010. Effect of wastewater irrigation on vegetables in relation to bioaccumulation of heavy metals and biochemical changes. Environmental Monitoring and Assessment, 165, 169-177.

76. Ghosh, A. K., Bhatt, M. A., Agrawal, H. P. 2012. Effect of longterm application of treated sewage water on heavy metal accumulation in vegetables grown in Northern India. Environmental Monitoring and Assessment, 184 (2), 1025-1036.

77. Xue, Z.-J., Liu, S. -Q., Liu, Y. -L., Yan, Y. -L. 2012. Health risk assessment of heavy metals for edible parts of vegetable grown in sewage-irrigated soils in suburbs of Baoding city, China. Environmental Monitoring and Assessment, 184, 3503-3513.

78. Copaciu, F., Opris, O., Coman, V., Ristoiu, D., Niinemets, Ü., Copolovici, L. 2013. Diffuse water pollution by anthraquinone and azo dyes in environment importantly alters foliage volatiles, carotenoids and physiology in wheat (Triticum aestivum). Water, Air, and Soil Pollution, 224(3), 1478. 


\section{Figures caption}

Figure 1. Plant morphology of tomato as influenced by ground and different stages of textile dyeing waste water. ( $\mathrm{T} 1=$ Ground water/control, $\mathrm{T} 2=2^{\text {nd }}$ wash after scouring and bleaching, $\mathrm{T} 3=$ Enzyme treated water, $\mathrm{T} 4=2^{\text {nd }}$ wash after bath drain, $\mathrm{T} 5=$ Neutralization treatment, $\mathrm{T} 6$ $=2^{\text {nd }}$ wash after soaping, $\mathrm{T} 7=$ Fixing treatment water, $\mathrm{T} 8=$ Mixed effluent, $\mathrm{DAT}=$ Days after transplanting, $*=\leq \mathrm{P} 0.05,{ }^{*}=\mathrm{P} \leq 0.01, * * *=\mathrm{P} \leq 0.001$ )

Figure 2. Correlation matrix in between and among yield attributes, nutrient efficiency, SAR, $\mathrm{EF}$ and PLI during and after tomato cultivation. [ $\mathrm{UE}=$ use efficiency, $\mathrm{EF}=$ enrichment factor, $\mathrm{PLI}=$ pollution load index].

Figure 3. Principal Component Analysis (PCA) of yield attributes, nutrient efficiency, SAR, enrichment factor (EF) and Pollution load index (PLI) during and after tomato cultivation. [(A) PCA of the variables showing their major contribution, (B) PCA-Biplot analysis representing the clustering of ground water and different stages of textile dyeing waste water towards major contribution. [ UE = use efficiency, SAR = sodium absorption ratio, T1= Ground water (control), T2 $=2^{\text {nd }}$ wash after scouring and bleaching, T3 $=$ Enzyme treated water, $\mathrm{T} 4=2^{\text {nd }}$ wash after bath drain, $\mathrm{T} 5=$ Neutralization treatment, $\mathrm{T} 6=2^{\text {nd }}$ wash after soaping, T7 = Fixing treatment water, T8 = Mixed effluent]. 
Figures

\section{Figure 1}

Plant morphology of tomato as influenced by ground and different stages of textile dyeing waste water. $\left(\mathrm{T} 1=\right.$ Ground water/control, $\mathrm{T} 2=2^{\text {nd }}$ wash after scouring and bleaching, $\mathrm{T} 3=$ Enzyme treated water, $\mathrm{T} 4=$ $2^{\text {nd }}$ wash after bath drain, $\mathrm{T} 5=$ Neutralization treatment, $\mathrm{T} 6=2^{\text {nd }}$ wash after soaping, $\mathrm{T} 7=$ Fixing treatment water, T8 $=$ Mixed effluent, DAT $=$ Days after transplanting, $*=\leq P 0.05, * \star=P \leq 0.01, \star \star \star=$ $\mathrm{P} \leq 0.001)$ 

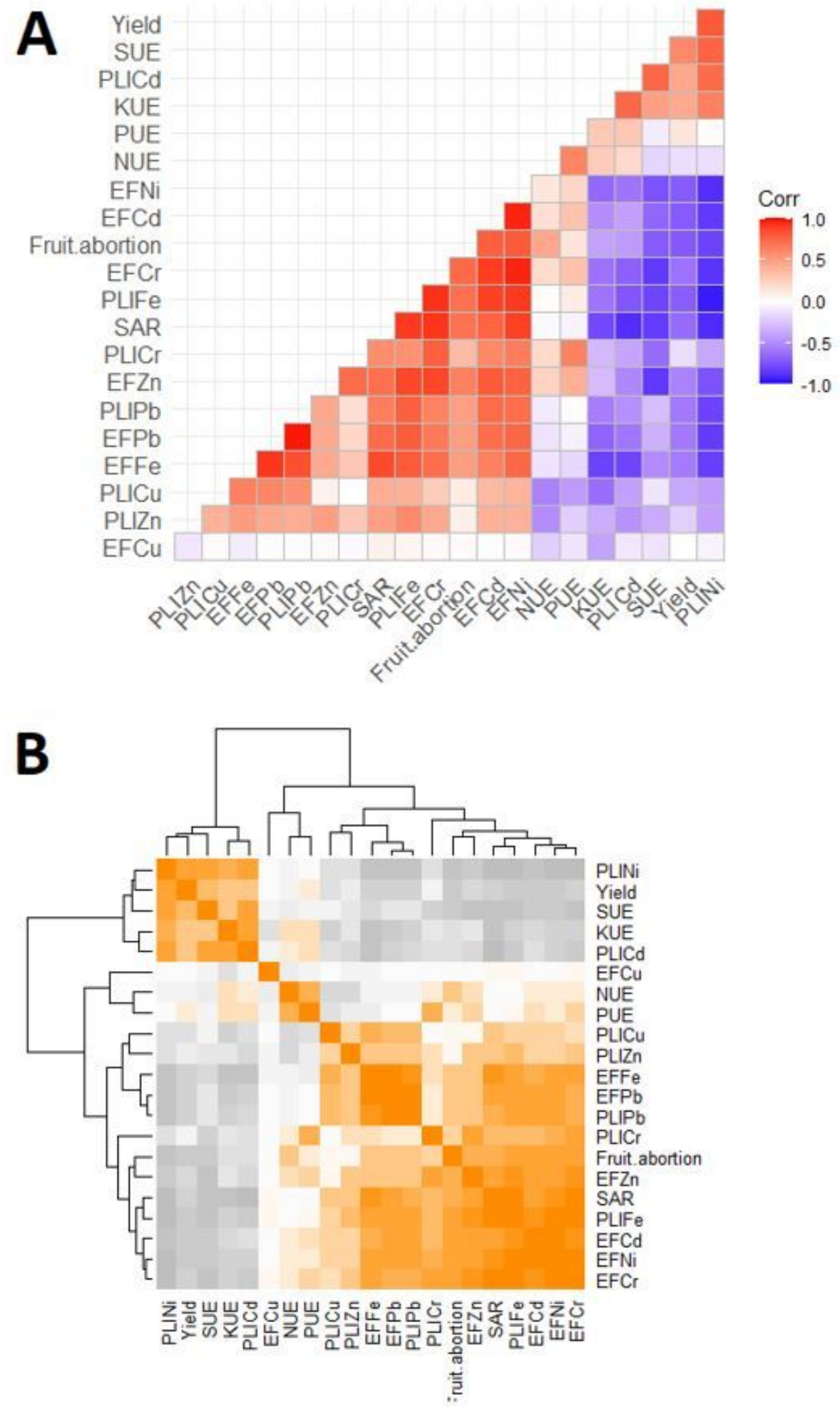

Figure 2

Correlation matrix in between and among yield attributes, nutrient efficiency, SAR, EF and PLI during and after tomato cultivation. [ UE = use efficiency, EF = enrichment factor, $\mathrm{PLI}=$ pollution load index]. 

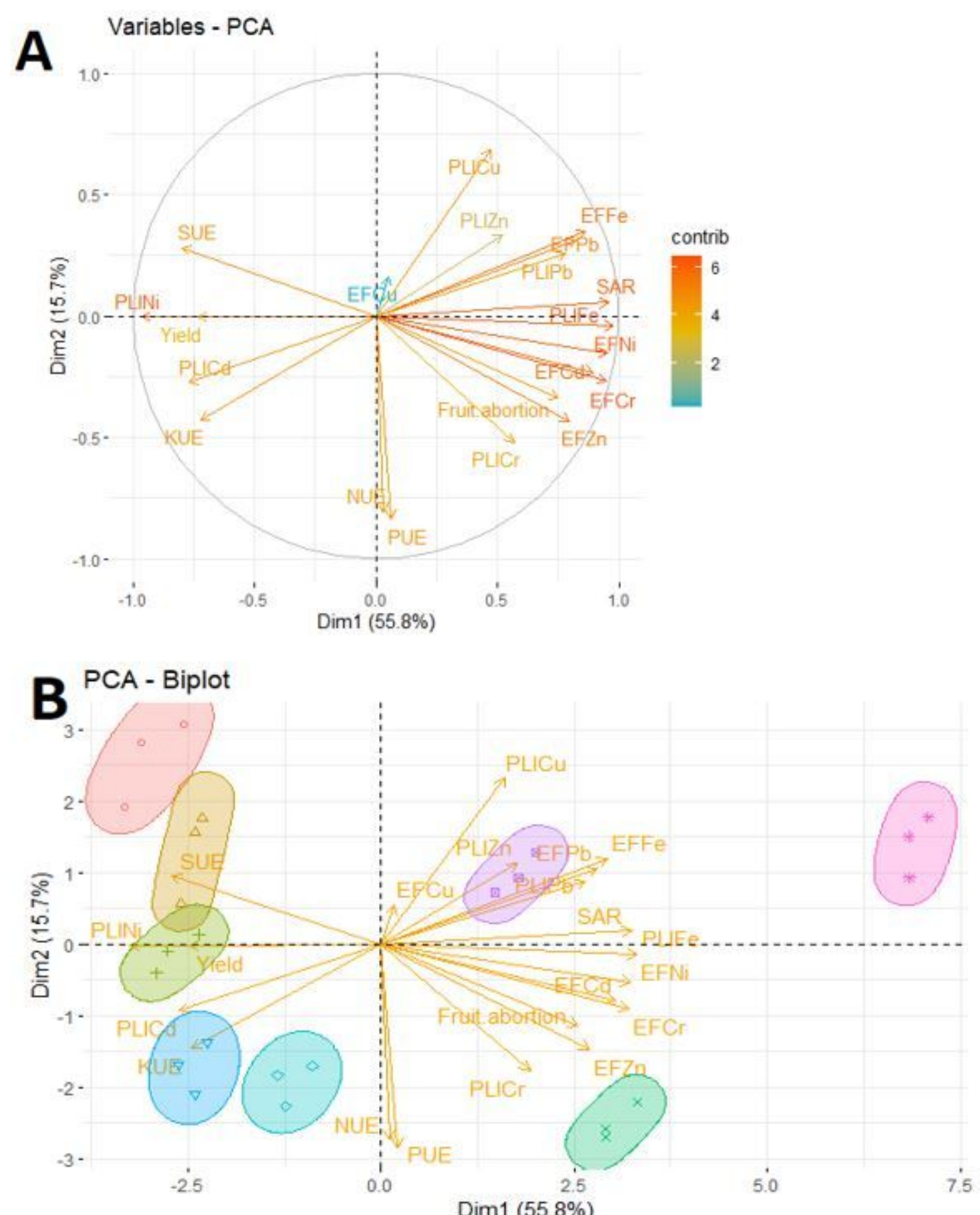

$\operatorname{Dim} 1(55.8 \%)$

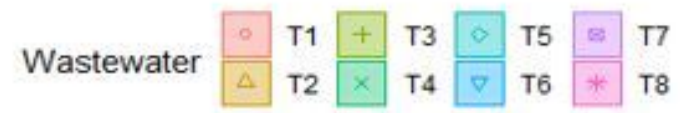

\section{Figure 3}

Principal Component Analysis (PCA) of yield attributes, nutrient efficiency, SAR, enrichment factor (EF) and Pollution load index (PLI) during and after tomato cultivation. [(A) PCA of the variables showing their major contribution, (B) PCA-Biplot analysis representing the clustering of ground water and different stages of textile dyeing waste water towards major contribution. [ UE = use efficiency, SAR = sodium absorption ratio, $\mathrm{T} 1=$ Ground water (control), $\mathrm{T} 2=2^{\text {nd }}$ wash after scouring and bleaching, $\mathrm{T} 3=$ Enzyme 
treated water, $\mathrm{T} 4=2^{\text {nd }}$ wash after bath drain, $\mathrm{T} 5=$ Neutralization treatment, $\mathrm{T} 6=2^{\text {nd }}$ wash after soaping, $\mathrm{T} 7$ = Fixing treatment water, $\mathrm{T} 8=$ Mixed effluent] .

\section{Supplementary Files}

This is a list of supplementary files associated with this preprint. Click to download.

- GraphicalAbstractWWTomatoScientificReports9Dec21.png 